\title{
STRATEGI PERLINDUNGAN LAHAN PERTANIAN PANGAN BERKELANJUTAN DI KABUPATEN TANGERANG
}

\section{Strategy For Protection Of Sustainable Food Crop Agricultural Land In Tangerang Regency}

\author{
Anna Karenina ${ }^{1}$, Ernan Rustiadi $^{2}$, Yusman Syaukat $^{3}$ \\ ${ }^{1}$ Staff Pengajar Program Studi Perencanaan Wilayah dan Kota, Institut Teknologi Indonesia. Email: \\ ${ }^{2}$ Staff Pengajar Departemen Ilmu Tanah, Fakultas Pertanian, IPB. Email: ernan@indo.net.id \\ ${ }^{3}$ Staff Pengajar Departemen Ekonomi Sumberdaya dan Lingkungan, Fakultas Ekonomi dan Manajemen, IPB. \\ Email: ysyaukat@apps.ipb.ac.id
}

\begin{abstract}
The study was based on the issue faced by the agricultural sector in Tangerang Regency which is the conversion of irrigated land. This conversion occurred due to increased population growth and economic development in Tangerang Regency, as the buffer zone of Special Capital Region of Jakarta. This issue led to the shrinkage of irrigated land area and endangerment of food security in Tangerang Regency, which acted as one of the national granary. The purpose of this study was to formulate a strategy for the protection of sustainable food crop agricultural land in Tangerang Regency. A review of Regional Regulation (Perda) No.13, 2011 on Regional Spatial Planning (RTRW) of Tangerang Regency was carried out to achieve that purpose. Methods used in this study were the analytical overlay model and descriptive analysis in which the formulation of protection strategy was performed using the SWOT analysis model. The results showed that there was a potential reclamation of irrigated land area into non-irrigated land or conversion of 23,755.19 ha irrigated land area in Tangerang Regency. The results of SWOT analysis which is to identify internal and external factors, several strategies could be formulated, among others was doing protection against agricultural land conversion through the implementation control of RTRW.
\end{abstract}

Keywords: conversion of irrigated land, strategy for protection of food crop agricultural land, regional spatial planning $(R T R W)$

\begin{abstract}
ABSTRAK
Penelitian ini dilakukan berdasarkan pada permasalahan yang dihadapi oleh sektor pertanian di Kabupaten Tangerang berupa alih fungsi lahan sawah irigasi. Alih fungsi ini terjadi karena adanya pertumbuhan penduduk dan perkembangan ekonomi di wilayah Kabupaten Tangerang sebagai wilayah penyangga Daerah Khusus Ibukota Jakarta. Akibatnya adalah berdampak pada berkurangnya lahan sawah irigasi dan terancamnya ketahanan pangan di Kabupaten Tangerang yang berperan sebagai lumbung padi nasional. Tujuan penelitian ini adalah untuk merumuskan strategi perlindungan lahan pertanian tanaman pangan berkelanjutan di Kabupaten Tangerang. Tinjauan Peraturan Daerah (Perda) No.13, 2011 tentang Rencana Tata Ruang Wilayah (RTRW) Kabupaten Tangerang dilakukan untuk mencapai tujuan tersebut. Metode yang digunakan dalam penelitian ini adalah model overlay analitis dan analisis deskriptif di mana perumusan strategi perlindungan dilakukan dengan menggunakan model analisis SWOT. Hasil penelitian menunjukkan bahwa ada potensi reklamasi lahan sawah irigasi menjadi lahan non-irigasi atau konversi lahan sawah irigasi seluas 23.755,19 ha di Kabupaten Tangerang. Hasil analisis SWOT yaitu untuk mengidentifikasi faktor internal dan eksternal, beberapa strategi dapat dirumuskan, antara lain melakukan perlindungan terhadap konversi lahan pertanian melalui pengendalian pelaksanaan RTRW.
\end{abstract}

Kata kunci: konversi lahan beririgasi, strategi perlindungan lahan pertanian tanaman pangan, perencanaan tata ruang wilayah (RTRW)

\section{PENDAHULUAN}

Kabupaten Tangerang merupakan salah satu kabupaten yang ada di Provinsi Banten yang memiliki sistem pertanian yang cukup baik. Hal ini dikarenakan selain jenis tanah yang subur untuk pertanian, juga memiliki luas lahan sawah yang cukup besar diposisikan oleh pemerintah 
pusat sebagai salah satu daerah penyedia pangan di Indonesia. Namun, luas lahan sawah yang ada di Kabupaten Tangerang mengalami penyusutan. Jika dilihat dari tahun 1984 terjadi penurunan luas lahan pertanian dari seluas $85,411.38$ ha menjadi $67,528.60$ ha pada tahun 2009 (Martini, 2011). Dalam rentang waktu 20 tahun ke depan diprediksi lahan itu akan terus berkurang. Setiap tahunnya luas lahan sawah ini cenderung mengalami penurunan, dimana pada tahun 2010 luas lahan sawah yang ada sebesar 39,915 ha dan mengalami penurunan hingga 38,322 ha pada tahun 2014 (BPS, Kabupaten Dalam Angka tahun 2014).

Upaya strategis dalam pengendalian alih fungsi lahan pertanian dan perlindungan terhadap lahan pertanian produktif perlu didukung oleh suatu peraturan perundangundangan, dimulai tahun 1960 dengan Undang-undang Pokok Agraria (UUPA), kemudian pada tahun 2009 diterbitkan Undang-Undang No. 41 tentang Perlindungan Lahan Pertanian Berkelanjutan. Namun ketentuan pada UU No. 41 ini perlu dijabarkan lebih lanjut oleh Pemerintah Daerah sebagaimana diamanahkan bahwa Provinsi Kabupaten/Kota diharuskan mengidentifikasi lahan pertanian pangan berkelanjutan yang dilanjutkan dengan penetapan kawasan pertanian pangan berkelanjutan melalui Peraturan Daerah Rencana Tata Ruang Wilayah (RTRW) sehingga keberlanjutan lahan pertanian pangan dapat tetap terjaga.

Permasalahan peningkatan alih fungsi lahan yang terjadi menurut Rachmat dan Muslim (2013) disebabkan adanya kebijakan pemerintah daerah (kabupaten/kota) yang berkecenderungan mengkonversi lahan sawah atasnama kepentingan pembangunan daerahnya. Hal ini ditunjukkan oleh data RTRW kabupaten/kota di seluruh Indonesia yang dihimpun BPN yang menunjukkan adanya keinginan untuk mengalihfungsikan lahan sawah seluas 3.09 juta ha yang merupakan $42.37 \%$ dari areal sawah beririgasi atau $34.81 \%$ dari total lahan sawah. Penyebab lainnya adalah karena Pemerintah Kabupaten Tangerang belum memiliki rencana yang lebih rinci dari RTRW (RDTR), maka hanya Perda Np 13 tahun 2011 tentang RTRW Kabupaten Tangerang yang dapat digunakan sebagai instrumen pengendalian pemanfaatan ruang yang sudah barang tentu kurang memadai.

Mengingat sektor pertanian merupakan salah satu sektor yang diunggulkan, namun di lain pihak alih fungsi lahan sawah yang terus terjadi di Kabupaten Tangerang, tentunya ini akan mengganggu ketahanan pangan. Untuk itu diperlukan adanya jaminan ketersediaan lahan pertanian. Dengan demikian dirasakan perlu dilakukan kajian tentang strategi perlindungan lahan pertanian pangan berkelanjutan di Kabupaten Tangerang.

Dalam rangka melakukan kajian tentang strategi tersebut, maka tujuan penelitian ini adalah (1) menganalisis seberapa besar penggunaan lahan sawah irigasi di Kabupaten Tangerang yang sesuai dengan arahan peruntukan ruang pada Perda No. 13 tahun 2011 tentang RTRW Kabupaten Tangerang, (2) menganalisis seberapa besar perubahan penggunaan lahan sawah irigasi di Kecamatan Sepatan yang sesuai dengan arahan RTRW Kabupaten Tangerang (setelah ditetapkannya Perda No. 13 tahun 2011), serta (3) merumuskan strategi perlindungan lahan pertanian pangan berkelanjutan di Kabupaten Tangerang.

\section{METODE PENELITIAN}

Adanya pertumbuhan penduduk dan perkembangan ekonomi yang meningkat pesat di Kabupaten Tangerang yang salah satunya adalah akibat Kabupaten Tangerang sebagai wilayah penyangga Ibukota Jakarta. Kondisi tersebut menjadi penyebab terjadinya peningkatan kebutuhan lahan untuk permukiman dan kegiatan ekonomi khususnya untuk kegiatan industri. Akibatnya adalah terjadi alih fungsi lahan pertanian ke non pertanian yang antara lain akan berdampak pada ketersediaan lahan sawah irigasi berkurang dan ketahanan pangan Kabupaten Tangerang yang berperan sebagai lumbung padi nasional terancam. Untuk itu maka perlu strategi perlindungan lahan pertanian pangan berkelanjutan di Kabupaten Tangerang. Kerangka pemikiran dari penelitian ini dapat dilihat pada Gambar 1.

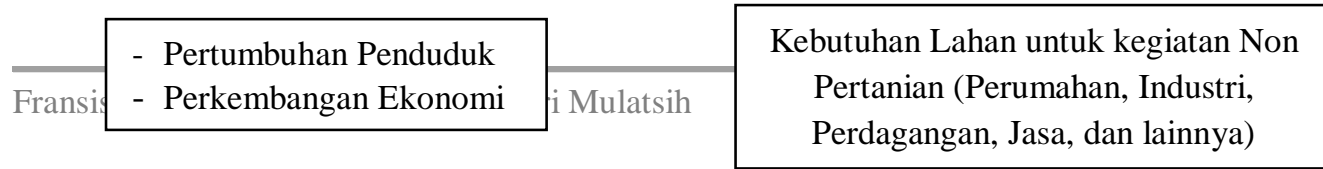




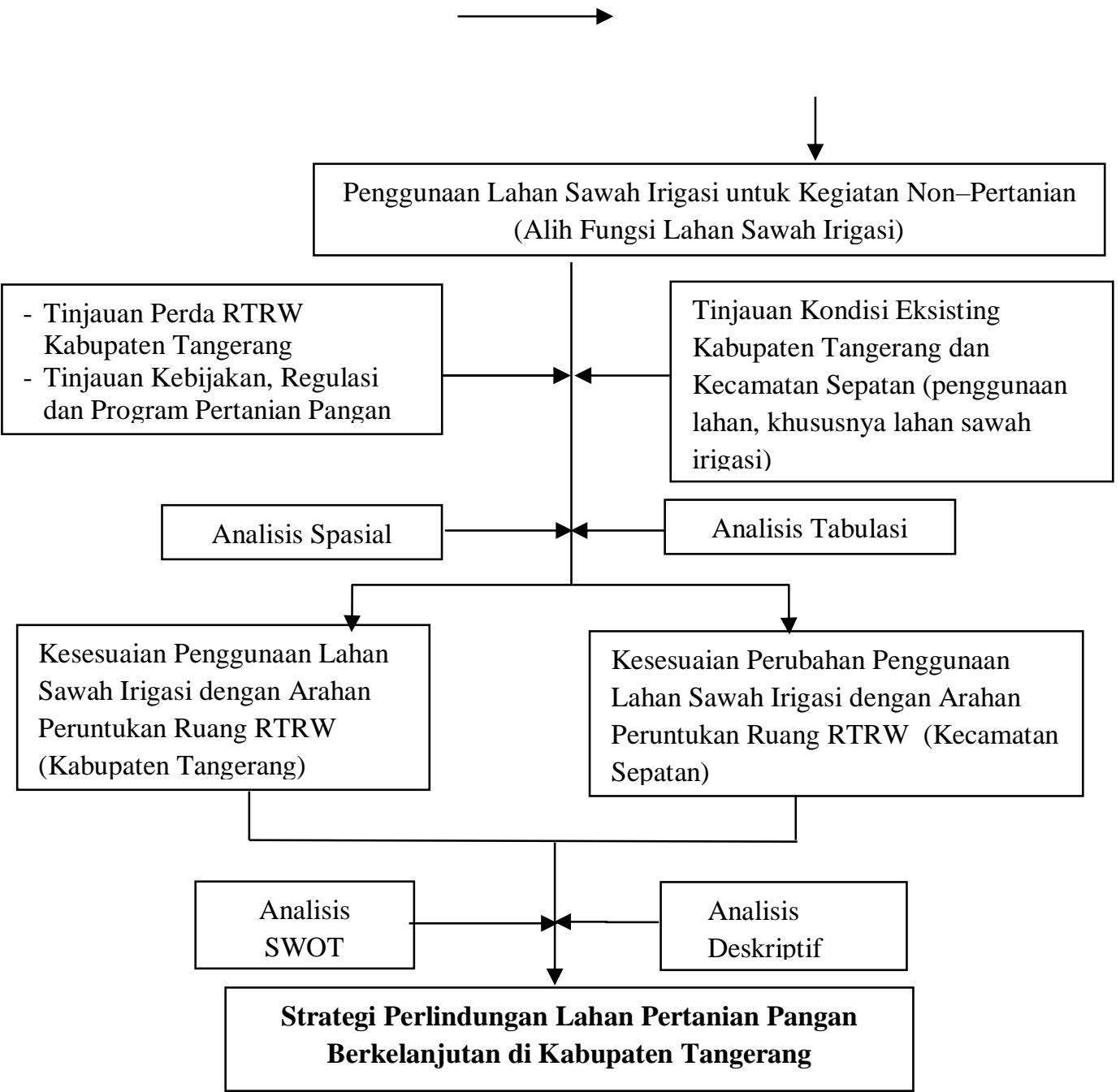

Gambar 1 Kerangka Pemikiran

Penelitian dilakukan di wilayah Kabupaten Tangerang, Provinsi Banten dan dilaksanakan selama 6 bulan di mulai dari bulan Mei sampai dengan bulan November 2015 . Selanjutnya dipilih satu kecamatan yang diamati lebih rinci tentang alih fungsi lahan yang terjadi pada kecamatan yang terlihat banyak mengalami alih fungsi lahan sawah irigasinya yaitu Kecamatan Sepatan.

Metode analisis yang digunakan adalah metode analisis sistem informasi geografis (SIG) dengan melakukan teknik analisis tumpang susun peta yaitu menganalisis obyek penelitian melalui peta dengan cara menumpangsusunkan (overlay) antara peta satu dengan peta lainnya sehingga menghasilkan informasi yang diinginkan secara spasial. Teknik ini menggunakan software yang sudah diinstal dalam perangkat komputer yaitu Arc-Gis 10, untuk kemudian mengolah data spasial berupa file shp.

Analisis tumpang susun data spatial pertama dilakukan antara Peta Penggunaan Lahan Kabupaten Tangerang tahun 2008 dengan Peta Pola Ruang Perda RTRW. Hasilnya diketahui adanya lahan sawah irigasi yang tetap sebagai lahan sawah irigasi sesuai arahan peruntukan pertanian pada Perda RTRW, lahan sawah irigasi yang berpotensi menjadi non-sawah irigasi sesuai dengan arahan peruntukan pertanian pada Perda RTRW, dan penggunaan lahan nonsawah irigasi berpotensi menjadi lahan sawah irigasi (cetak sawah) sesuai arahan peruntukan pertanian pada Perda RTRW.

Analisis tumpang susun data spatial kedua dilakukan antara Peta Penggunaan Lahan Kecamatan Sepatan tahun 2012 dengan Peta Penggunaan Lahan Kecamatan Sepatan tahun 2015 dan Peta Pola Ruang Perda RTRW di wilayah Kecamatan Sepatan. Hasil tumpang susun 
ketiga peta tersebut, kemudian diketahui adanya perubahan lahan sawah menjadi non-sawah yang terjadi antara tahun 2012-2015 yang sesuai dengan RTRW, potensi terjadinya perubahan lahan sawah menjadi non-sawah setelah tahun 2015 yang sesuai dengan RTRW, terjadinya perubahan lahan sawah menjadi non-sawah antara 2012-2015 yang terindikasi pelanggaran, adanya potensi perubahan lahan non-sawah menjadi sawah sesuai RTRW (adanya potensi cetak lahan sawah baru) dan lahan sawah yang tidak mengalami perubahan sejak tahun 2012 sesuai RTRW.

Untuk merumuskan strategi perlindungan lahan pertanian pangan berkelanjutan di Kabupaten Tangerang digunakan metoda SWOT. SWOT adalah akronim untuk kekuatan (strenghts), kelemahan (weaknessess), peluang (opportunities), dan ancaman (threats). Menurut Ferrel dan Harline (2005), fungsi analisis SWOT adalah untuk mendapatkan informasi dari analisis situasi dan memisahkannya dalam pokok persoalan internal (kekuatan dan kelemahan) dan pokok persoalan eksternal (peluang dan ancaman). Analisis SWOT adalah identifikasi berbagai faktor secara sistematis untuk merumuskan strategi. Analisis ini didasarkan pada logika yang dapat memaksimalkan kekuatan dan peluang, namun secara bersamaan dapat meminimalkan kelemahan dan ancaman. Proses pengambilan keputusan strategi selalu berkaitan dengan pengembangan misi, tujuan, strategi, dan kebijakan (kekuatan, kelemahan, peluang, dan ancaman) dalam kondisi saat ini (Rangkuti 2007).

Metode analisis, keluaran, jenis dan sumber data yang dibutuhkan sesuai dengan tujuan yang ingin dicapai dapat dilihat pada Tabel 1.

Tabel 1 Matriks hubungan antara tujuan, metode analisis, keluaran, jenis dan sumber data

\begin{tabular}{|c|c|c|c|c|c|}
\hline No & Tujuan penelitian & $\begin{array}{l}\text { Metode } \\
\text { analisis }\end{array}$ & Keluaran & Jenis data & Sumber Data \\
\hline 1 & $\begin{array}{l}\text { Menganalisis seberapa } \\
\text { besar penggunaan lahan } \\
\text { sawah irigasi di } \\
\text { Kabupaten Tangerang } \\
\text { yang sesuai dengan } \\
\text { arahan peruntukan ruang } \\
\text { pada Perda No. } 13 \text { tahun } \\
\text { 2011 tentang RTRW } \\
\text { Kabupaten Tangerang. }\end{array}$ & $\begin{array}{l}\text { Analisis } \\
\text { Tumpang } \\
\text { Susun }\end{array}$ & $\begin{array}{l}\text { Luasan lahan } \\
\text { sawah irigasi } \\
\text { yang sesuai } \\
\text { dengan RTRW }\end{array}$ & $\begin{array}{l}\text { Peta Penggunaan } \\
\text { Lahan Kabupaten } \\
\text { Tangerang tahun } \\
\text { 2008 dan Rencana } \\
\text { Pola Ruang } \\
\text { Kabupaten } \\
\text { Tangerang tahun } \\
\text { 2011-2031 }\end{array}$ & $\begin{array}{l}\text { Citra Landsat Tahun } \\
\text { 2008, Perda No } 13 \\
\text { tahun } 2011 \text { Tentang } \\
\text { RTRW Kabupaten } \\
\text { Tangerang }\end{array}$ \\
\hline 2 & $\begin{array}{l}\text { Menganalisis seberapa } \\
\text { besar perubahan } \\
\text { penggunaan lahan sawah } \\
\text { irigasi di Kecamatan } \\
\text { Sepatan yang sesuai } \\
\text { dengan arahan RTRW } \\
\text { Kabupaten Tangerang } \\
\text { (setelah ditetapkannya } \\
\text { Perda No } 13 \text { tahun } \\
\text { 2011). }\end{array}$ & $\begin{array}{l}\text { Analisis } \\
\text { Tumpang } \\
\text { Susun }\end{array}$ & $\begin{array}{l}\text { Luasan } \\
\text { perubahan } \\
\text { penggunaan } \\
\text { lahan sawah } \\
\text { irigasi }\end{array}$ & $\begin{array}{l}\text { Peta Penggunaan } \\
\text { Lahan Kecamatan } \\
\text { Sepatan tahun } 2012 \\
\text { dan 2015, serta } \\
\text { Peta Pola Ruang } \\
\text { Kabupaten } \\
\text { Tangerang tahun } \\
\text { 2011-2031 }\end{array}$ & $\begin{array}{l}\text { Intepretasi Citra } \\
\text { Satelit, diakses } \\
\text { Desember tahun } 2012 \\
\text { dalam Matek RDTR } \\
\text { Kecamatan Sepatan; } \\
\text { Citra Satelit, diakses } \\
\text { Agustus tahun 2015, } \\
\text { dari Google Earth }\end{array}$ \\
\hline 3 & $\begin{array}{l}\text { Merumuskan strategi } \\
\text { perlindungan lahan } \\
\text { pertanian pangan } \\
\text { berkelanjutan di } \\
\text { Kabupaten Tangerang }\end{array}$ & $\begin{array}{l}\text { Analisis } \\
\text { SWOT }\end{array}$ & $\begin{array}{l}\text { Strategi } \\
\text { Perlindungan } \\
\text { Lahan } \\
\text { Pertanian } \\
\text { Pangan } \\
\text { Berkelanjutan } \\
\text { di Kabupaten } \\
\text { Tangerang }\end{array}$ & $\begin{array}{l}\text { Hasil Olahan dari } \\
\text { Data Sekunder dan } \\
\text { Primer (informan) }\end{array}$ & \\
\hline
\end{tabular}

\section{HASIL DAN PEMBAHASAN}

Arahan peruntukan pertanian dalam batang tubuh perda no 13 tahun 2011 adalah sebesar 29,295 ha, namun demikian arahan peruntukan lahan sawah irigasi pada peta pola ruang perda 
tersebut hanya seluas 24,755.45 ha. Hal ini memperlihatkan adanya ketidakkonsistenan arahan peruntukan lahan pertanian di Kabupaten Tangerang dengan adanya perbedaan yang cukup signifikan antara data peruntukkan lahan pertanian yang tercantum dalam batang tubuh dengan data spasial dalam peta rencana pola ruang dalam RTRW Kabupaten Tangerang yaitu seluas 4,359.55 ha. Oleh karena itu arahan peruntukkan ruang yang telah ditetapkan harus ditinjau kembali. Selanjutnya untuk perhitungan analisis tumpang susun digunakan luasan arahan peruntukkan pertanian sebesar 24,755.45 ha.

Kesesuaian penggunaan lahan sawah irigasi dengan arahan peruntukan pertanian dalam RTRW Kabupaten Tangerang adalah tentang besarnya lahan sawah irigasi yang sesuai dengan RTRW Kabupaten Tangerang. Kesesuaian ini dilakukan dengan menggunakan analisis tumpang susun sistem informasi geografis antara penggunaan lahan sawah irigasi eksisting hasil dari interpretasi citra satelit tahun 2008 dengan arahan peruntukan pertanian dalam RTRW. Hasil perhitungan data spasial ini diperoleh bahwa lahan sawah irigasi yang masih sesuai dengan arahan peruntukkan lahan pertanian dalam RTRW Kabupaten Tangerang sebesar 21,954.94 ha, lahan yang mempunyai potensi menjadi lahan sawah sebesar 2,800.51 ha dan, lahan sawah irigasi yang potensi untuk berubah ke penggunaan lain (direncanakan dialihfungsikan ke penggunaan bukan sawah) adalah sebesar 23,755.19 ha (lihat Gambar 2).

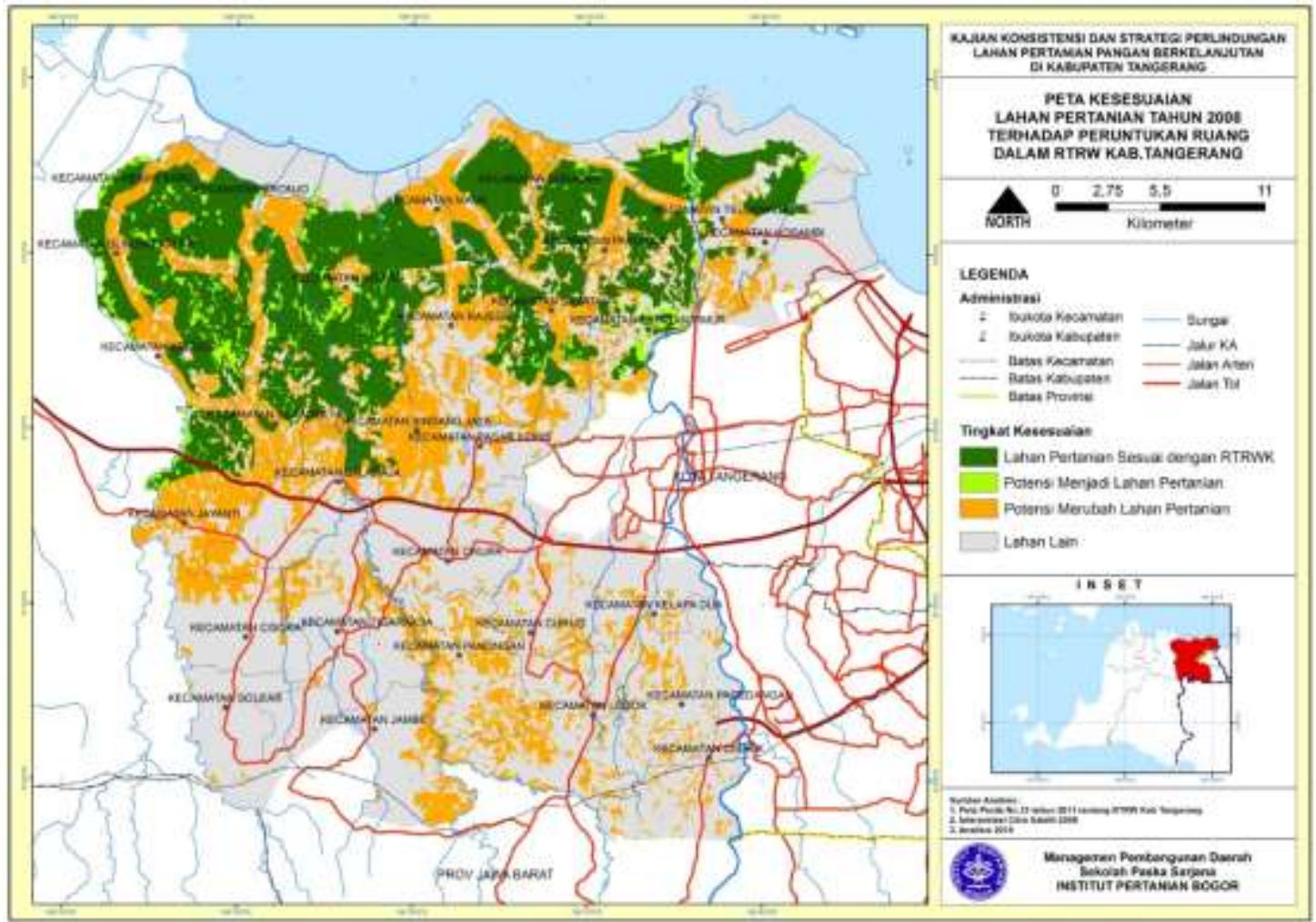

Gambar 2 Peta kesesuaian penggunaan lahan tahun 2008 dengan arahan peruntukan ruang dalan RTRW Kabupaten Tangerang 2011-2031

Kesesuaian perubahan penggunaan lahan sawah irigasi di Kecamatan Sepatan (tahun 2012-2015) dan arahan Peruntukan Pertanian dalam RTRW Kabupaten Tangerang dilakukan dengan teknik tumpang susun antara peta penggunaan lahan Kecamatan Sepatan tahun 2012 dengan peta penggunaan lahan Kecamatan Sepatan tahun 2015 dan peta pola ruang Perda RTRW di wilayah Kecamatan Sepatan. Hasil tumpang susun ketiga peta tersebut dapat dilihat pada Tabel 2 dan Gambar 3. Perubahan penggunaan lahan sawah irigasi yang sesuai dengan RTRW adalah sebesar 101.61 ha terjadi paling besar adalah di desa Pondok Jaya, hal ini sesuai dengan hasil pengamatan 


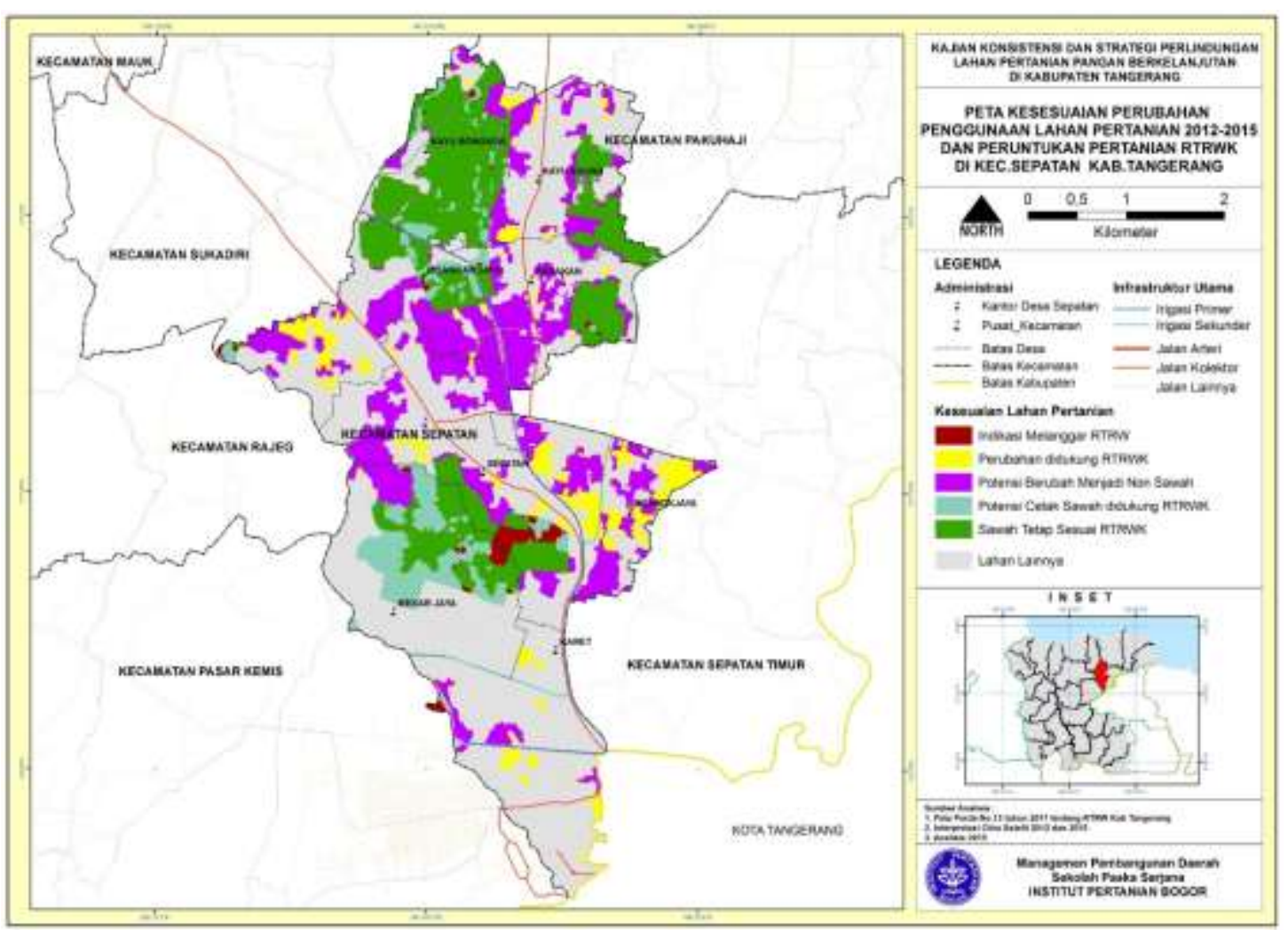

Gambar 3 Peta kesesuaian perubahan penggunaan lahan sawah irigasi 2012-2015 di Kecamatan Sepatan dengan arahan peruntukan pertanian dalam RTRW Kabupaten Tangerang

Tabel 2 Kesesuaian perubahan penggunaan lahan sawah irigasi di Kecamatan Sepatan (tahun 2012-2015) dengan arahan peruntukan pertanian dalam RTRW Kabupaten Tangerang

\begin{tabular}{|l|r|r|r|r|r|r|r|}
\hline $\begin{array}{c}\text { Kelurahan/ } \\
\text { Desa }\end{array}$ & $\begin{array}{c}\text { Indikasi } \\
\text { Melanggar } \\
\text { RTRW } \\
\text { (ha) }\end{array}$ & $\begin{array}{c}\text { Perubahan } \\
\text { sesuai } \\
\text { RTRW } \\
\text { (ha) }\end{array}$ & $\begin{array}{c}\text { Potensi } \\
\text { Berubah } \\
\text { Sesuai } \\
\text { RTRW } \\
\text { (ha) } \\
\text { S2 }\end{array}$ & $\begin{array}{c}\text { SL-1 } \\
\text { SLawah } \\
\text { Sesuai } \\
\text { RTRW } \\
\text { (ha) } \\
\text { S }\end{array}$ & $\begin{array}{c}\text { Setap } \\
\text { Sawah Sesuai } \\
\text { (ha) } \\
\text { L-1 }\end{array}$ & $\begin{array}{c}\text { Potensi Cetak } \\
\text { Lainnya } \\
\text { (ha) }\end{array}$ & Total (ha) \\
\hline Sepatan & 10.02 & 9.90 & 75.52 & 35.26 & 5.01 & 179.59 & 315.29 \\
\hline Pisangan Jaya & 1.67 & 20.88 & 70.60 & 35.07 & 17.01 & 106.39 & 251.62 \\
\hline Kayu Bongkok & 2.26 & 3.48 & 11.95 & 122.28 & 18.29 & 28.05 & 186.31 \\
\hline Karet & 1.33 & 12.73 & 14.59 & 0 & 0.69 & 236.29 & 265.65 \\
\hline Mekar Jaya & 6.14 & 0.66 & 16.65 & 54.31 & 74.04 & 146.23 & 298.04 \\
\hline Sarakan & 0.75 & 3.70 & 55.01 & 32.22 & 3.73 & 77.26 & 172.67 \\
\hline Kayuagung & 0.26 & 7.08 & 44.52 & 49.91 & 2.29 & 112.29 & 216.35 \\
\hline Pondok Jaya & 0 & 43.17 & 56.80 & 0 & 0 & 77.29 & 177.26 \\
\hline Total & 22.44 & 101.61 & 345.64 & 329.05 & 121.07 & 963.40 & $1,883.20$ \\
\hline
\end{tabular}

\section{Keterangan :}

SL-2 = Penggunaan Sawah menjadi Non Sawah Indikasi Pelanggaran RTRW

SL-1 = Penggunaan Sawah menjadi Non Swah didukung RTRW

S2 = Penggunaan Sawah Potensi Berubah ke Penggunaan Non-Sawah sesuai/didukung RTRW

$\mathrm{S} \quad=$ Penggunaan Sawah Tetap Sawah sesuai/didukung RTRW

L1 = Penggunaan Lain Potensi Jadi Sawah (Cetak Sawah)

lapangan dan melakukan wawancara kepada beberapa narasumber, bahwa desa Pondok Jaya merupakan desa yang paling berkembang pesat perubahan penggunaan lahan dikarenakan desa Pondok Jaya merupakan satu satu nya desa yang penggunaan lahan sawah irigasi yang ada saat ini tidak dialokasikan lagi arahan peruntukan pertanian dalam RTRW. Untuk indikasi pelanggaran sebesar 22.44 ha dan potensi berubah sesuai RTRW sebesar 345.64 ha, dimana terbesar terjadi di Kelurahan Sepatan. Adapun untuk sawah yang tetap bertahan menjadi sawah sebesar 329.05 ha, terbesar di Desa Kayu Bongkok dan untuk cetak sawah sebesar 121.07 ha terbesar ada di Desa Mekar Jaya. Strategi yang dapat dilakukan dari hasil analisis SWOT dapat dilihat pada Tabel 3 . 
Tabel 3. Matriks SWOT strategi perlindungan lahan pertanian pangan berkelanjutan di Kabupaten Tangerang

\begin{tabular}{|c|c|c|}
\hline Faktor Eksternal & $\begin{array}{l}\text { Kekuatan }(\text { Strenghts }) \\
\text { S1 }=\text { Produktivitas Padi Sawah } \\
\quad \text { GKG Tinggi } \\
\text { S2 = Intensitas Panen Padi Sawah } \\
\text { S3 = Potensi Lahan Sawah Irigasi } \\
\text { S4 = Potensi Cetak Sawah sesuai } \\
\text { RTRW } \\
\text { S5 }=\text { Jenis dan Tekstur Tanah }\end{array}$ & $\begin{aligned} & \text { Kelemahan }(\text { Weaknesses }) \\
& \text { W1 }= \text { Motivasi Petani Rendah } \\
& \text { W2 }= \text { Kondisi Ekonomi Petani } \\
& \text { W3 }= \text { Tingkat Pendidikan } \\
& \text { Petani } \\
& \text { W4 }= \text { Sifat Kepemilikan Tanah } \\
& \text { Warisan } \\
& \text { W5 }= \text { Belum adanya RDTR } \\
& \text { Kecamatan Sepatan } \\
& \text { W6 }= \text { RTRW Penyebab Alih } \\
& \text { Fungsi Lahan Sawah } \\
& \text { Irigasi } \\
& \text { W7 }= \text { Penyusutan Lahan } \\
& \text { Pertanian Sawah } \\
& \text { W8 }= \text { Keterbatasan kepemilikan } \\
& \text { lahan sawah } \\
& \text { W9 }= \text { Harga Lahan } \\
& \text { W10= } \text { Kurangnya Dukungan } \\
& \text { Pemerintah dalam } \\
& \text { Pemeliharaan Saluran } \\
& \text { Irigasi }\end{aligned}$ \\
\hline $\begin{aligned} & \text { Peluang }(\text { Opportunities }) \\
& \mathrm{O} 1= \begin{array}{l}\text { Dukungan Kebijakan } \\
\text { Pemerintah Provinsi },\end{array} \\
& \text { Kabupaten } / \text { Kota } \\
& \mathrm{O} 2= \begin{array}{l}\text { Kebijakan Agropolitan } \\
\text { (pada Perda RTRW }\end{array} \\
&\text { Kabupaten Tangerang }) \\
& \mathrm{O} 3= \text { Penetapan Kabupaten } \\
& \begin{array}{l}\text { Tangerang sebagai Lahan } \\
\text { Sawah Irigasi Teknis }\end{array} \\
& \mathrm{O} 4= \begin{array}{l}\text { Pendataan lahan pertanian } \\
\text { pangan beserta }\end{array} \\
& \text { cadangannya }\end{aligned}$ & $\begin{array}{l}\text { Strategi S-O } \\
\text { 1. Pengembangan Sistem Informasi } \\
\text { Spatial untuk Lahan Potensi Sawah } \\
\text { Irigasi (S1,S2, S3 - O3, O5) } \\
\text { 2. Penetapan Lahan Pertanian Pangan } \\
\text { Berkelanjutan pada Rencana Tata } \\
\text { Ruang (S3, S4 - O1, O2, O4) }\end{array}$ & $\begin{array}{l}\text { Strategi W-O } \\
\text { 1. Percepatan Penyusunan dan } \\
\text { Penetapan Perda RDTR } \\
\text { Kecamatan Sepatan (W5, W6 } \\
\text { - O1, O2, O3, O5) } \\
\text { 2. Peningkatan Peran Koperasi } \\
\text { (W2 - O6, O7) } \\
\text { 3. Pembentukan Badan Usaha } \\
\text { dan Kemitraan dengan } \\
\text { Perbankan (W1, W2 - O7) }\end{array}$ \\
\hline $\begin{aligned} & \text { Ancaman }(\text { Threats }) \\
& \mathrm{T} 1= \text { Jarak Kecamatan Sepatan } \\
& \text { dengan Bandara Soekarno } \\
& \text { Hatta dan Kota Tangerang } \\
& \mathrm{T} 2= \text { Konsistensi Perencanaan } \\
& \text { RTRW } \\
& \mathrm{T} 3= \text { Proporsi Tenaga Kerja } \\
& \text { Kabupaten Tangerang } \\
& \mathrm{T} 4= \text { Penyusutan Luas Lahan } \\
& \text { Pertanian Kabupaten } \\
& \text { Tangerang } \\
& \mathrm{T} 5= \text { Arahan Peruntukkan } \\
& \text { Ruang tidak Mendukung } \\
& \text { Pertanian Sawah }\end{aligned}$ & $\begin{array}{l}\text { Strategi S-T } \\
\text { 1. Penghentian Perpanjangan Ijin } \\
\text { Pemanfaatan Ruang di Lahan } \\
\text { Peruntukan Pertanian (S3, S4 - } \\
\text { T6) } \\
\text { 2. Melakukan Peninjauan Kembali } \\
\text { dan Revisi Perda RTRW } \\
\text { Kabupaten Tangerang (S3 - T2, } \\
\text { T5) Pengendalian } \\
\text { 3. Sosialisasi Puan sesuai RTRW } \\
\text { Pemanfaatan Ruang sal } \\
\text { (S3-T1) }\end{array}$ & $\begin{array}{l}\text { Strategi W-T } \\
\text { 1. Pengembangan Pelatihan } \\
\text { Sektor Pertanian (W2, W3 - } \\
\text { T3) } \\
\text { 2. Penetapan NJOP sesuai } \\
\text { Arahan Peruntukan Ruang } \\
\text { RTRW (W4, W9 - T7) } \\
\text { 3. Mencegah dan Menindak } \\
\text { Terjadinya Pelanggaran (W7 - } \\
\text { T6) }\end{array}$ \\
\hline
\end{tabular}




\begin{tabular}{|l|l|l|}
\hline $\mathrm{T} 6=$ & Lemahnya Pengendalian \\
& terhadap Pelanggaran Tata \\
& Ruang & \\
$\mathrm{T} 7=$ & Tidak adanya Pengendalian & \\
& $\begin{array}{l}\text { Harga Tanah sesuai } \\
\text { Arahan Peruntukkan }\end{array}$ & \\
& Ruang & \\
\hline
\end{tabular}

\section{SIMPULAN}

Simpulan yang dapat diambil dari hasil dan pembahasan yang telah dilakukan adalah sebagai berikut:

1) Perda no 13 tahun 2011 tentang RTRW Kabupaten Tangerang 2011-2031 mengarahkan perubahan penggunaan lahan sawah irigasi ke penggunaan bukan sawah irigasi sebesar 23,755.19 ha atau $52 \%$ dari total luas lahan sawah yang ada (45,710.12 ha.). Adapun luas lahan sawah irigasi yang masih sesuai dengan arahan peruntukkan lahan pertanian dalam RTRW Kabupaten Tangerang sebesar 21,954.94 ha atau 48\% dari total luas sawah yang ada, serta lahan yang mempunyai potensi menjadi lahan sawah sebesar 2,800.51 ha.

2) Perubahan penggunaan lahan sawah irigasi yang sesuai RTRW di Kecamatan Sepatan pada tahun 2012-2015 adalah sebesar 101.61 ha, indikasi pelanggaran sebesar 22.44 ha, potensi berubah sesuai RTRW sebesar 345.64 ha, sawah yang tetap bertahan menjadi sawah sebesar 329.05 ha, dan untuk potensi cetak sawah sebesar 121.07 ha.

3) Berdasarkan hasil analisis SWOT terhadap faktor-faktor internal dan eksternal, maka dapat dirumuskan 11 strategi perlindungan lahan pertanian pangan berkelanjutan di Kabupaten Tangerang yaitu pengembangan sistem informasi spatial untuk lahan potensi sawah irigasi, penetapan lahan pertanian pangan berkelanjutan pada rencana tata ruang, percepatan penyusunan dan penetapan Perda RDTR Kecamatan Sepatan, peningkatan peran koperasi, pembentukan badan usaha dan kemitraan dengan perbankan, penghentian perpanjangan ijin pemanfaatan ruang di lahan peruntukan pertanian, melakukan peninjauan kembali dan revisi perda RTRW Kabupaten Tangerang, sosialisasi pengendalian pemanfaatan ruang sesuai RTRW, pengembangan pelatihan sektor pertanian, penetapan NJOP sesuai arahan peruntukan ruang RTRW, serta mencegah dan menindak terjadinya pelanggaran.

\section{DAFTAR PUSTAKA}

[ESRI] Environmental at System Research Institute, 1990. Understanding GIS: The Arc/Info Method Environmental at System Research Institute. Redlands, California (US): ESRI.

Ferrel OC, Harline D. 2005. Marketing Strategy. South Western: Thomson Corporation.

Gunawan I. 1998. Typiycal Geografic Information System (GIS) Aplication For Coastal Resources Management Indonesia. Jurnal Pengelolaan Sumberdaya Pesisir dan Lautan Indonesia. I (1): 1-12.

Isa, I. 2006. Strategi Pengendalian Alih Fungsi Lahan Pertanian. http://balittanah .litbang.deptan.go.id/dokumentasi/prosiding/mflp2006/.

Martini, S. 2011. Analisis Dampak Perubahan Penggunaan Tanah Terhadap Lingkungan di Kabupaten Tangerang. Sekolah Pasca Sarjana, Thesis, Institut Pertanian Bogor, Bogor.

Nugroho I, Dahuri R. 2004. Pembangunan Wilayah: Persepsi Ekonomi, Sosial dan Lingkungan. Jakarta, LP3ES.

Pesandaran, E, 2006. Alternatif Kebijakan Pengendalian Konversi Lahan Sawah Beririgasi di Indonesia. Jurnal Litbang Pertanian. 25(4):123-129. 
Rachmat M, Muslim C. 2013. Peran dan Tantangan Implementasi UU 41/2009 dalam Melindungi Lahan Pertanian Pangan Berkelanjutan. Kemandirian Pangan Indonesia dalam Presfektif Kebijakan MP3EI. Badan Penelitian dan Pengembangan Pertanian. Kementerian Pertanian, Jakarta.

Rangkuti F. 2007. Analisis SWOT: Teknik Membedah Kasus Bisnis. PT Gramedia Pustaka Utama, Jakarta.

Pemerintah Republik Indonesia. 2007. Undang-Undang Nomor 26 tahun 2007 tentang Penataan Ruang, Jakarta (ID): Sekretariat Negara.

Pemerintah Republik Indonesia. 2009. Undang-Undang Nomor 41 tahun 2009 tentang Pelindungan Lahan Pertanian Pangan Berkelanjutan. Jakarta (ID): Sekertariat Negara.

Pemerintah Daerah Kabupaten Tangerang. 2011. Peraturan Daerah (Perda) no 13 tahun 2011 tentang Rencana Tata Ruang Wilayah Kabupaten Tangerang

[BPS] Biro Pusat Statistik, Kabupaten Tangerang Dalam Angka tahun 2004-2014 